\title{
Perioperativ kjemoterapi ved ventrikkelcancer
}

\author{
Kjemoterapi er forbundet med \\ betydelig toksisitet, og bare $40 \%$ \\ gjennomfører behandlingen som \\ planlagt.
}

Langtidsoverlevelsen etter operasjon for kreft i ventrikkelen er lav. En randomisert studie publisert i 2006 viste at overlevelsen økte fra $23 \%$ til $36 \%$ når kjemoterapi med epirubicin, cisplatin og 5-fluorouracil ble gitt før og etter operasjon (1). Norsk gastrointestinal cancergruppe (NGICG) anbefalte derfor at perioperativ kjemoterapi skulle innføres i det nasjonale handlingsprogrammet. I en nylig publisert artikkel ble innføringen av retningslinjene evaluert (2).

Av 336 opererte pasienter hadde 144 (43\%) fått kjemoterapi. $90 \%$ gjennomførte de preoperative kurene, $54 \%$ startet og $40 \%$ gjennomførte den postoperative behandlingen. Alvorlige bivirkninger ble rapportert hos $34 \%$ før operasjon og hos $50 \%$ etter operasjon. Én pasient døde som følge av bivirkninger og to av kirurgiske komplikasjoner. $86 \%$ ble makro- og mikroskopisk radikaloperert. Hos $5 \%$ kunne det ikke påvises gjenværende tumorvev etter kjemoterapi. 19 av 25 sykehus innførte retningslinjene det første året. Ett sykehus hadde ikke innført dem etter to og et halvt år.

Undersøkelsen presenterer for første gang populasjonsbaserte data om perioperativ kjemoterapi ved ventrikkelcancer. Den bekrefter det kliniske inntrykket av at denne behandlingen er belastende. Halvparten av pasientene med ventrikkelcancer er over 75 år, og mange vil ikke tåle slik behandling.

I et landsomfattende materiale som dette må andelen radikalopererte karakteriseres som høyt. Det er ennå for tidlig å vurdere kjemoterapiens betydning for langtidsoverlevelse.

\section{Toto Hølmebakk}

toto.holmebakk@oslo-universitetssykehus.no Avdeling for gastroenterologisk kirurgi Oslo universitetssykehus

\section{Litteratur}

1. Cunningham D, Allum WH, Stenning SP et al. Perioperative chemotherapy versus surgery alone for resectable gastroesophageal cancer. N Engl J Med 2006; 355: 11-20

2. Hølmebakk T, Frykholm G, Viste A. Introducing national guidelines on perioperative chemotherapy for gastric cancer in Norway: A retrospective audit. Eur J Surg Oncol 2010; 36: 610-6.

\section{Skriveøvelse kan redusere kjønnsforskjeller i realfag}

I mange teknologiske og matematiske fag skårer kvinner dårligere enn menn på tester. Nå har amerikanske forskere undersøkt effekten av en psykologisk intervensjon for å redusere kjønnsforskjeller i fysikkprestasjoner (Science 2010; 330: 1234-7).

399 collegestudenter ved et introduksjonskurs i fysikk ble randomisert til å skrive om sine viktigste verdier, f.eks. familie og venner, to ganger i begynnelsen av kurset eller ikke å gjøre det. Skriveøvelsen reduserte kjønnsforskjeller i læring og yteevne vesentlig, og karakternivået for de kvinnelige studentene ble hevet fra C til B. Forbedringen var størst hos de kvinnene som mente at menn var bedre enn kvinner i fysikk. Resultatene viste at en kortvarig psykologisk intervensjon kan bidra til å redusere kjønnsforskjeller i vitenskapelige prestasjoner.

\section{Ulike antibiotika - samme effekt}

En rekke antibiotika er like gode ved ukomplisert urinveisinfeksjon hos kvinner. Det er ikke forskjell i klinisk effekt, men litt bedre bakteriologisk effekt ved bruk av fluorokinoloner enn ved betalaktamer, men det vurderes ikke som klinisk relevant (Cochrane Database Syst Rev 2010: nr. 10: CD007182).

Analysen omfattet 21 randomiserte, kontrollerte studier med $i$ alt 6016 pasienter. Behandlingslengden for de ulike antibiotika var 3-10 dager. Trimetoprim med sulfametoksazol var like effektivt som fluourokinoloner for å oppnå symptomatisk lindring på både kort og lang sikt (RR 1). Det samme gjaldt også ved sammenlikning med betalaktamantibiotika og nitrofurantoin.

\section{Psykiatriske akuttavdelinger gjør jobben sin}

\section{Over halvparten av pasientene hadde klinisk signifikant bedring og $98 \%$ noe bedring etter median 13 døgns opp- hold i psykiatrisk akuttavdeling.}

Akuttavdelinger er en viktig del av det psykiatriske helsevesenet. Likevel har det vært få effektstudier av innleggelser ved slike enheter, som har som oppgave å dempe symptomtrykket så raskt som mulig og å identifisere pasienter med symptomer som skyldes somatisk sykdom. En betydelig andel av innleggelsene skjer med tvang. Liggetiden er blitt stadig kortere.

I en ny norsk undersøkelse fra to akuttposter ved Psykiatrisk avdeling, Sunnmøre sykehus, var median liggetid 13 døgn (1). 186 pasienter ble undersøkt ved innleggelsen, og 147 av dem også ved utskrivingen, med bruk av den intervjubaserte Brief Psychiatric Rating Scale (BPRS) som primært resultatmål. Klinisk betydningsfull endring, dvs. minst $10 \%$ reduksjon av BPRS-totalskår, ble oppnådd hos $56 \%$ av pasientene (95\% KI 48\%-64\%), mindre enn $10 \%$ bedring ble observert hos $42 \%$ av pasientene, men hos $2 \%$ var situasjonen uforandret. Tvangsinnleggelse hadde ingen signifikant sammenheng med behandlingsresultatet. Ved innleggelse var $59 \%$ under

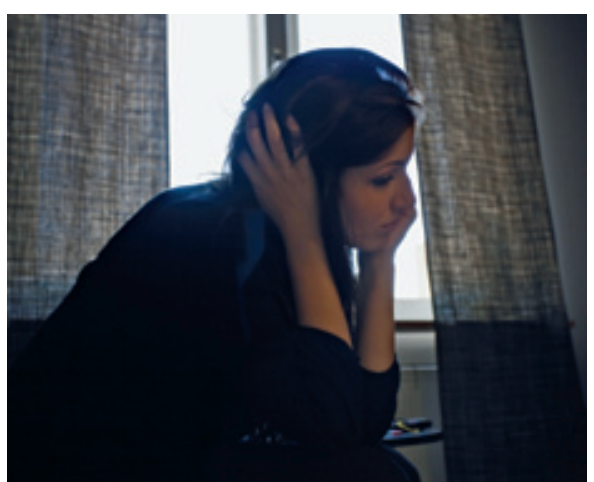

SCANPIX

fast behandling med psykofarmaka, ved utskrivingen gjaldt dette for $89 \%$.

I denne pre-post-designen var det ikke mulig å si om bedringen skyldtes behandlingen eller ikke. Remedisinering synes å være et vanlig tiltak ved akuttavdelinger.

\section{Alv A. Dahl}

alv.a.dahl@oslo-universitetssykehus.no Oslo universitetssykehus

\section{Litteratur}

1. Svindseth MF, Nøttestad JA, Dahl AA. A study of outcome in patients treated at a psychiatric emergency unit. Nord J Psychiatry 2010; 64: 363-71. 